(C)Carcinological Society of Japan. doi: 10.18353/crustacea.47.0_111

\title{
Genetic population structure of Sphaeroma wadai Nunomura, 1994 (Isopoda: Sphaeromatidae) along the Japanese coast
}

\author{
Jun Kitaura, Ryuta Yoshida, Noboru Nunomura
}

\begin{abstract}
DNA sequences from a portion of the mitochondrial 16S rRNA gene were used to examine genetic differentiation among the local coastal populations of the Japanese wood-boring isopod Sphaeroma wadai Nunomura, 1994. Of the 15 haplotypes identified, only 3 were shared among the sampled localities. The most dominant haplotype was shared by all populations from the Japanese mainland. All haplotypes identified from Okinawa Island and Iriomote Island were endemic to each island. For the Japanese mainland group, the haplotype network showed a star-like shape, with rare haplotypes radiating from the central most common haplotype by only one or two mutation steps. Haplotypes identified from Iriomote Island were separated by many steps from those identified from all other sampled localities, and haplotypes identified from Okinawa Island were separated by several steps from those identified from the Japanese mainland. Phylogenetic analyses revealed the existence of two lineages: one comprising specimens from Iriomote Island and the other comprising specimens from the Japanese mainland and Okinawa Island. These two lineages diverged at an uncorrected $p$-distance of $9.1 \%-10.3 \%$, probably representing a different species. There were no clear morphological differences between the two lineages except for the propodus length of the seventh pereopod of male individuals.
\end{abstract}

Key words: Genetic structure, $16 S$ rRNA, mtDNA, Japanese wood-boring isopod, morphological variation

\section{Introduction}

The genus Sphaeroma Bosc, 1802 is distributed worldwide and approximately 40 species are reported to date (Boyko et al., 2008). From Japan, seven species are known, including $S$. terebrans Bate, 1866; S. sieboldii Dollfus, 1889; S. retrolaevis Richardson, 1904; S. wadai Nunomura, 1994; S. shimantoensis Nunomura, 2003; S. mukaii Nunomura, 2006; and S. rotundicaudum Nunomura, 2008. Four of the seven known species, $S$. wadai, S. shimantoensis, $S$. mukaii, and $S$. rotundicaudum, are considered endemic to Japan, and they (except $S$. wadai) have been reported only from their type localities so far.
The richness of local species might be correlated with their characteristic life forms. The life history and population biology of the genus Sphaeroma have been studied for several species, including $S$. hookeri Leach, 1814 (Jensen, 1955; Kouwenberg and Pinkster, 1985), $S$. quadridentatum Say, 1818 (Borowsky, 1996), S. rugicauda Leach, 1814 (Harvey, 1969; Heath and Khazaeli, 1985), S. serratum Fabricius, 1787 (Harvey, 1969; Kittlein, 1991), S. terebrans (Thiel, 1999), S. wadai (Murata and Wada, 2002) and S. walkeri Stebbing, 1905 (Ounifi et al., 2015). Among these, S. terebrans and $S$. wadai show boring habits. Sphaeroma wadai is mainly distributed in the inner parts of a bay, inhabiting burrows in sandstone and de- 
caying wood, where it completes the reproductive cycle (Murata and Wada, 2000; 2002). Females release offspring from the brood pouch in their own burrows and live together until the offspring grow to a certain stage. Observations in tide-simulation tanks have indicated little activity outside burrows (Murata and Wada, 2000), suggesting that adult movement is very limited. No early dispersal stage and low active dispersal ability of adult would limit gene flow among regional populations, resulting in the existence of a large number of local species. The life history of Sphaeroma terebrans is similar to that of $S$. wadai and is characterized by its low active dispersal (Messana et al., 1994; Thiel, 1999; Messana, 2004). Nevertheless, molecular phylogeographic analysis suggests that $S$. terebrans disperses great distances by rafting on floating wood, while the physical barriers posed by coastal topography limit the gene flow to nearby localities (Baratti et al., 2005; 2011).

The aim of the present study was to investigate whether the genetic and morphological differentiation can be seen among the populations of $S$. wadai. We collected specimens along the Japanese coasts and determined the mitochondrial genes of 16S rRNA (16S) and cytochrome $c$ oxidase subunit I (COI), which were used in the phylogeographic studies of congeneric S. terebrans (Baratti et al., 2005; 2011). However, the PCR success rate of COI was low in the specimens of $S$. wadai; thus, only $16 \mathrm{~S}$ dataset were analyzed in this study. The phylogenetic relationships among six Japanese Sphaeroma species and eight Sphaeroma species from the public databases were analyzed to elucidate the current phylogenetic position of $S$. wadai.

\section{Materials and Methods}

\section{Samples}

In total, 323 individuals of S. wadai from 13 localities (including its type locality, Tanabe Bay, Wakayama) from the Japanese mainland and the Ryukyu Islands were collected to examine genetic differentiation (Table 1, Fig. 1). In addition, surveys were conducted in Osaka (Yodo River and Onosato River), Miyagi (Nanakita River, Natori River, and Matsushima Bay), and Fukushima (Matsukawa Bay) Prefectures, but no $S$. wadai individuals were observed.

Table 1. Sampling localities and sample size for Sphaeroma wadai.

\begin{tabular}{lccccc}
\hline \multicolumn{1}{c}{ Collection locality } & $\begin{array}{c}\text { Locality } \\
\text { number }\end{array}$ & Latitude & Longitude & Collection date \\
\hline Isumi Riv., Chiba Pref. & 1 & $35^{\circ} 17^{\prime} \mathrm{N}$ & $140^{\circ} 24^{\prime} \mathrm{E}$ & $15 / \mathrm{June} / 2016$, coll. by JK & 29 \\
Tama Riv., Kanagawa Pref. & 2 & $35^{\circ} 32^{\prime} \mathrm{N}$ & $139^{\circ} 45^{\prime} \mathrm{E}$ & $14 / \mathrm{June} / 2016$, coll. by JK & 30 \\
Harai Riv., Mie Pref. & 3 & $34^{\circ} 35^{\prime} \mathrm{N}$ & $136^{\circ} 37^{\prime} \mathrm{E}$ & $28 / \mathrm{Feb} / 2016$, coll. by JK & 30 \\
Uchinoura, Wakayama Pref. & 4 & $33^{\circ} 41^{\prime} \mathrm{N}$ & $135^{\circ} 23^{\prime} \mathrm{E}$ & $13 / \mathrm{Feb} . / 2016$, coll. by JK & 10 \\
Samusaura, Wakayama Pref. & 4 & $33^{\circ} 40^{\prime} \mathrm{N}$ & $135^{\circ} 21^{\prime} \mathrm{E}$ & $13 / \mathrm{Feb} . / 2016$, coll. by JK & 18 \\
Arida Riv., Wakayama Pref. & 5 & $33^{\circ} 4^{\prime} \mathrm{N}$ & $135^{\circ} 7^{\prime} \mathrm{E}$ & $25 / \mathrm{Oct} / 2015$, coll. by JK & 29 \\
Katsuura Riv., Tokushima Pref. & 6 & $34^{\circ} 2^{\prime} \mathrm{N}$ & $134^{\circ} 34^{\prime} \mathrm{E}$ & $27 / \mathrm{Mar} / 2017$, coll. by JK & 30 \\
Kamo Riv., Ehime Pref. & 7 & $33^{\circ} 54^{\prime} \mathrm{N}$ & $133^{\circ} 10^{\prime} \mathrm{E}$ & $24 / \mathrm{May} / 2016$, coll. by KW & 15 \\
Shimanto Riv., Kochi Pref. & 8 & $32^{\circ} 57^{\prime} \mathrm{N}$ & $132^{\circ} 58^{\prime} \mathrm{E}$ & $25 / \mathrm{Mar} / 2016$, coll. by JK & 20 \\
& & $32^{\circ} 57^{\prime} \mathrm{N}$ & $132^{\circ} 59^{\prime} \mathrm{E}$ & $15 / \mathrm{Nov} . / 2016$, coll. by KW \& AN & 10 \\
Kita Riv., Miyazaki Pref. & 9 & $32^{\circ} 36^{\prime} \mathrm{N}$ & $131^{\circ} 41^{\prime} \mathrm{E}$ & $26 / \mathrm{Mar} / 2017$, coll. by JK & 30 \\
Manose Riv., Kagoshima Pref. & 10 & $31^{\circ} 26^{\prime} \mathrm{N}$ & $130^{\circ} 17^{\prime} \mathrm{E}$ & $27 / \mathrm{Mar} / 2017$, coll. by JK & 29 \\
Okukubi Riv., Okinawa Is., Okinawa Pref. & 11 & $26^{\circ} 27^{\prime} \mathrm{N}$ & $127^{\circ} 56^{\prime} \mathrm{E}$ & $20 /$ Aug./2017, coll. by JK & 30 \\
Urauchi Riv., Iriomote Is., Okinawa Pref. & 12 & $24^{\circ} 24^{\prime} \mathrm{N}$ & $123^{\circ} 46^{\prime} \mathrm{E}$ & $27 /$ Aug./2016, coll. by RY \\
Nakama Riv., Iriomote Is., Okinawa Pref. & 13 & $24^{\circ} 16^{\prime} \mathrm{N}$ & $123^{\circ} 52^{\prime} \mathrm{E}$ & $25-26 / \mathrm{Feb} . / 2017$, coll. by JK & 6 \\
\hline
\end{tabular}

Collector: JK, J. Kitaura; RY, R. Yoshida; KW, K. Wada; AN, A. Nomoto 


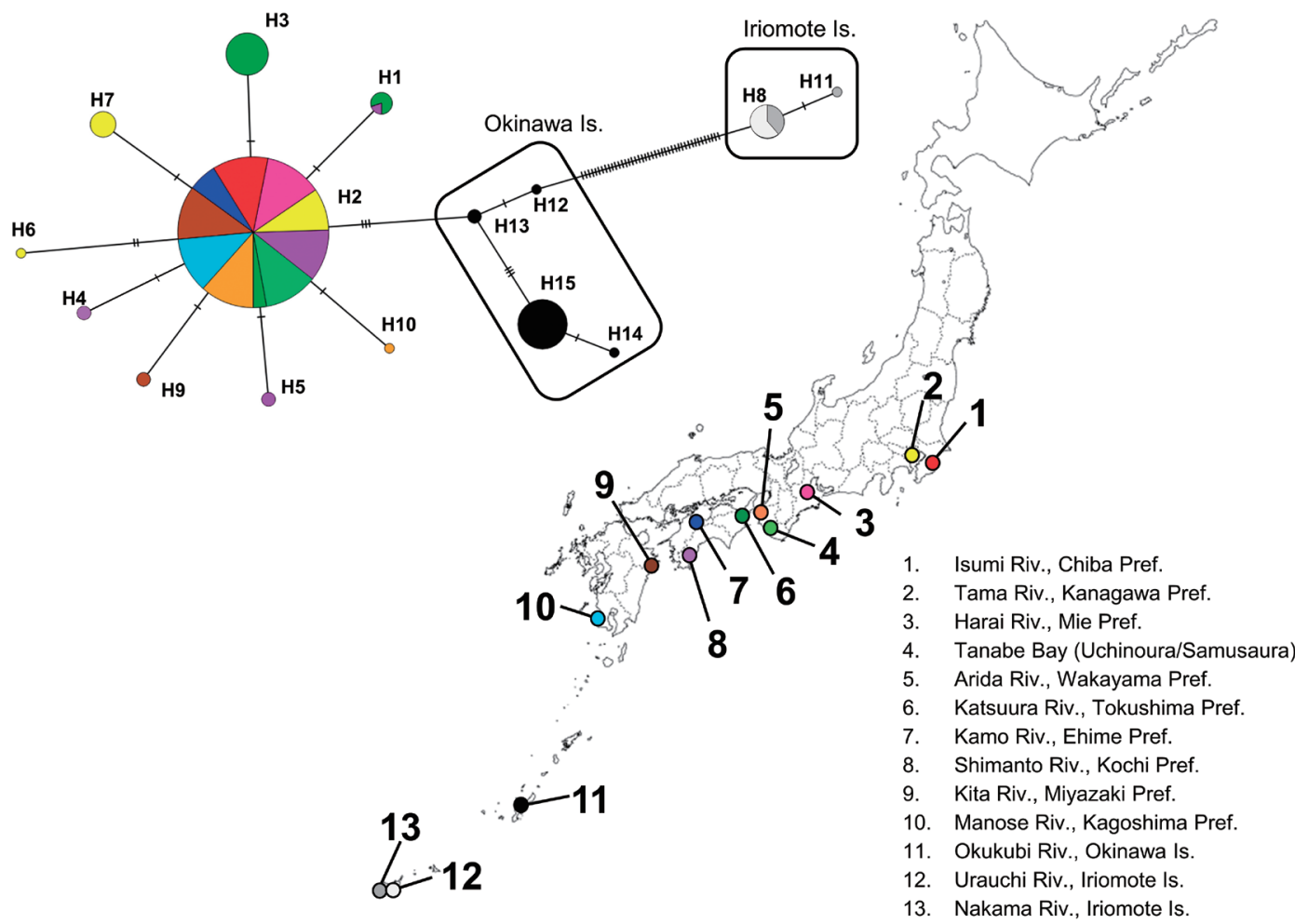

Fig. 1. Map of sampling localities for Sphaeroma wadai in Japan and a minimum spanning tree of haplotypes. Circle sizes are proportional to haplotype frequency, and each circle is color coded according to locality. Nucleotide substitutions among haplotypes are represented by dashes.

Table 2. List of species collected in the present study for phylogenetic analysis of the genus Sphaeroma, along with sampling localities and sequence accession number.

\begin{tabular}{|c|c|c|c|c|}
\hline \multirow[t]{2}{*}{ Species } & \multirow[t]{2}{*}{ Collection locality } & \multirow[t]{2}{*}{$\begin{array}{l}\text { Latitude/ } \\
\text { Longitude }\end{array}$} & \multirow[t]{2}{*}{ Collection date } & $\begin{array}{l}\text { Accession } \\
\text { nos. }\end{array}$ \\
\hline & & & & $16 \mathrm{~S}$ \\
\hline \multirow{5}{*}{$\begin{array}{l}\text { Sphaeroma wadai } \\
\text { Nunomura, } 1994\end{array}$} & Shimanto Riv., Kochi Pref. & $32^{\circ} 57^{\prime} \mathrm{N}, 132^{\circ} 58^{\prime} \mathrm{E}$ & 25/Mar./2016, coll. by JK & LC388436 \\
\hline & Uchinoura, Tanabe, Wakayama Pref. & $33^{\circ} 41^{\prime} \mathrm{N}, 135^{\circ} 23^{\prime} \mathrm{E}$ & 13/Feb./2016, coll. by JK & LC388437 \\
\hline & Okukubi Riv., Okinawa Is., Okinawa Pref. & $26^{\circ} 27^{\prime} \mathrm{N}, 127^{\circ} 56^{\prime} \mathrm{E}$ & 20/Aug./2017, coll. by JK & LC388438 \\
\hline & Nakama Riv., Iriomote Is., Okinawa Pref. & $24^{\circ} 16^{\prime} \mathrm{N}, 123^{\circ} 52^{\prime} \mathrm{E}$ & 25-26/Feb./2017, coll. by JK & LC388434 \\
\hline & Urauchi Riv., Iriomote Is., Okinawa Pref. & $24^{\circ} 24^{\prime} \mathrm{N}, 123^{\circ} 46^{\prime} \mathrm{E}$ & 27/Aug./2016, coll. by RY & LC388435 \\
\hline \multirow{2}{*}{$\begin{array}{l}\text { Sphaeroma retrolaevis } \\
\text { Richardson, } 1904\end{array}$} & Tama Riv., Kanagawa Pref. & $35^{\circ} 32^{\prime} \mathrm{N}, 139^{\circ} 45^{\prime} \mathrm{E}$ & 14/June/2016, coll. by JK & LC388429 \\
\hline & Katsuura Riv., Tokushima Pref. & $34^{\circ} 2^{\prime} \mathrm{N}, 134^{\circ} 34^{\prime} \mathrm{E}$ & 27/Mar./2017, coll. by JK & LC388430 \\
\hline $\begin{array}{l}\text { Sphaeroma shimantoensis } \\
\text { Nunomua, } 2003\end{array}$ & Shimanto Riv., Kochi Pref. & $32^{\circ} 57^{\prime} \mathrm{N}, 132^{\circ} 59^{\prime} \mathrm{E}$ & 15/Nov./2016, coll. by KW \& AN & LC388427 \\
\hline $\begin{array}{l}\text { Sphaeroma sieboldii } \\
\text { Dollfus, } 1889\end{array}$ & Samusaura, Shirahama, Wakayama Pref. & $33^{\circ} 40^{\prime} \mathrm{N}, 135^{\circ} 21^{\prime} \mathrm{E}$ & 13/Feb./2016, coll. by JK & LC388428 \\
\hline Sphaeroma sp. 1 & Kinokawa Riv., Wakayama Pref. & $34^{\circ} 14^{\prime} \mathrm{N}, 135^{\circ} 10^{\prime} \mathrm{E}$ & 25/Oct./2015, coll. by JK & LC388431 \\
\hline \multirow[t]{2}{*}{ Sphaeroma sp. 2} & Nadara Riv., Iriomote Is., Okinawa Pref. & $24^{\circ} 23^{\prime} \mathrm{N}, 123^{\circ} 49^{\prime} \mathrm{E}$ & 25-26/Feb./2017, coll. by JK & LC388432 \\
\hline & Urauchi Riv., Iriomote Is., Okinawa Pref. & $24^{\circ} 24^{\prime} \mathrm{N}, 123^{\circ} 46^{\prime} \mathrm{E}$ & 25-26/Feb./2017, coll. by JK & LC388433 \\
\hline
\end{tabular}

Collector: JK, J. Kitaura; RY, R. Yoshida; KW, K. Wada; AN, A. Nomoto 
Table 3. List of public data used for phylogenetic analysis of the genus Sphaeroma, along with sequence accession numbers and data source.

\begin{tabular}{|c|c|c|}
\hline \multirow{2}{*}{ Species } & ccession nos. & \multirow{2}{*}{ Source } \\
\hline & $16 \mathrm{~S}$ & \\
\hline \multirow[t]{6}{*}{ Sphaeroma terebrans Bate, 1866} & EF445550 & Baratti et al. (2011) \\
\hline & EF460859 & Baratti et al. (2011) \\
\hline & EF460858 & Baratti et al. (2011) \\
\hline & EF460854 & Baratti et al. (2011) \\
\hline & EF460857 & Baratti et al. (2011) \\
\hline & FJ666124 & Baratti et al. (2011) \\
\hline \multirow[t]{3}{*}{ Sphaeroma sp. } & EF460853 & Baratti et al. (2011) \\
\hline & EF460856 & Baratti et al. (2011) \\
\hline & EF460852 & Baratti et al. (2011) \\
\hline Sphaeroma sp. & EF460860 & Baratti et al. (2011) \\
\hline Sphaeroma serratum (Fabricius, 1787) & KU248278 & Wetzer et al. (2018) \\
\hline Sphaeroma quadridentatum Say, 1818 & KU248332 & Wetzer et al. (2018) \\
\hline Sphaeroma quoianum H. Milne Edwards, 1840 & KU248333 & Wetzer et al. (2018) \\
\hline Sphaeroma walkeri Stebbing, 1905 & KU248198 & Wetzer et al. (2018) \\
\hline Sphaeroma sp. & KU248329 & Wetzer et al. (2018) \\
\hline \multicolumn{3}{|l|}{ Outgroups } \\
\hline Oxinasphaera tetrodon Schotte \& Kensley, 2005 & KU248226 & Wetzer et al. (2018) \\
\hline Exosphaeroma truncatitelson Barnard, 1940 & KU248328 & Wetzer et al. (2018) \\
\hline
\end{tabular}

The species used for phylogenetic reconstructions are listed in Tables 2 and 3. These included six newly analyzed sequences from different Sphaeroma species (Table 2) and eight from public databases (Table 3). The sequences of Oxinasphaera tetrodon Schotte \& Kensley, 2005 and Exosphaeroma truncatitelson Barnard, 1940 were also obtained from the public database and were used as outgroups.

\section{DNA extraction, PCR amplification, and sequencing}

Total genomic DNA was extracted from the muscle tissue of pereopods using the GenElute Mammalian Genomic DNA Miniprep Kit (Sigma-Aldrich). Template DNA was amplified using the $16 \mathrm{~S}$ universal primers (16Sar 5'CGCCTGTTTATCAAAAACAT-3', 16Sbr 5'CCGGTCTGAACTCAGATCACGT-3', developed by Palumbi 1996). Touchdown PCR was performed using the Qiagen Multiplex PCR Kit, and PCR amplification was performed as follows. The DNA templates $(1-2 \mu \mathrm{l}), 2 \mu \mathrm{l}$ of $5 \times$ Q-solution, $10 \mu \mathrm{l}$ of $2 \times$ Qiagen Multiplex
PCR Master Mix, and $0.5 \mu \mathrm{l}$ of each primer $(10 \mu \mathrm{M})$ were mixed with distilled water to a total volume of $20 \mu \mathrm{l}$. The cycling conditions were as follows: initial heat activation at $94^{\circ} \mathrm{C}$ for $15 \mathrm{~min}$, followed by 9 cycles of denaturing at $94^{\circ} \mathrm{C}$ for $45 \mathrm{~s}$, annealing at $59^{\circ} \mathrm{C}$ (with $1{ }^{\circ} \mathrm{C}$ decrements each cycle) for $40 \mathrm{~s}$, and extension at $72^{\circ} \mathrm{C}$ for $90 \mathrm{~s}$. Further 30 cycles of denaturing at $94^{\circ} \mathrm{C}$ for $45 \mathrm{~s}$, annealing at $50^{\circ} \mathrm{C}$ for $45 \mathrm{~s}$, and extension at $72^{\circ} \mathrm{C}$ for $90 \mathrm{~s}$ were performed. The reaction was completed with a final extension for at $72^{\circ} \mathrm{C}$ for $10 \mathrm{~min}$. PCR products were purified using ExoSAP-IT (USB) and sequenced using the ABI BigDye Terminator version 3.1 in an ABI Prism 310 Genetic Analyzer. All final sequences were obtained from both strands for verification.

\section{Estimates of genetic diversity and population differentiation of S. wadai}

Basic parameters of molecular diversity, such as the number of haplotypes, nucleotide diversity, and haplotype diversity, were calculated for each $S$. wadai population using Arle- 
quin version 3.5 (Excoffier and Lischer, 2010). Estimates of population differentiation were obtained from pairwise $F_{\mathrm{ST}}$ calculations for the $16 \mathrm{~S}$ dataset using pairwise difference as a distance measure. Statistical significance was assessed through 10,000 permutations. All estimates and respective significance values were obtained using Arlequin version 3.5. The genealogical relationships among the identified haplotypes were represented by a minimum spanning tree (Bandelt et al., 1999) obtained using PopArt ver. 1.7 (Leigh and Bryant, 2015). Information on the frequency and distribution of haplotypes was depicted in the network by making circle sizes proportional to the haplotype frequency in the total sample and color coding them according to their frequency in each sampling location. The DNA sequences of haplotypes were deposited in DDBJ with accession numbers LC388646-LC388660.

\section{Phylogenetic analysis}

The sequences were aligned using CLUSTAL W (Thompson et al., 1994) with default gap penalties and then modified slightly by eye. Positions that could not be accurately aligned were excluded from the data sets, resulting in a total of $393 \mathrm{bp}$ (including gaps). Phylogenetic relationships were determined using Bayesian analysis, implemented in MrBayes v. 3.2 (Ronquist and Huelsenbeck, 2003). The model of nucleotide substitution that best fit the data set, as determined by the software KAKUSAN4 (Tanabe, 2007) using the Bayesian Information Criterion, was HKY + Gamma. Four Markov chains were run under the parameters of this model for 5,000,000 generations, sampled every 500th generation. The convergence of MCMC parameters and effective sample size were confirmed by Tracer 1.6 (Rambaut et al., 2014). The first 10\% generations were discarded as burn-in prior to tree building. The posterior probabilities of the phylogeny were determined by constructing a $50 \%$ majority-rule consensus of the remaining trees.

\section{Morphological examination}

We observed all diagnostic characters commonly used to identify Sphaeroma taxa at the species level (Harrison and Holdich, 1984; Jacobs, 1987), but there were no characteristics which could differentiate the populations. Therefore, a stereoscopic microscope was used to examine the characteristics showing individual variations (primarily countable traits; Table 4) between four individuals (two males and two females) from each genetically isolated local population identified throughout the study: Iriomote Island (Urauchi River), Okinawa Island, Katsuura River and Tama River, and Tanabe Bay (Samusaura and Uchinoura). We counted the number of the following features: tubercles on the dorsal surface of the sixth pereonal somite and pleotelson; flagellar segments of antennule and antenna; setae on the second and third segments of the mandible palp; setae on the mesial, middle, and lateral lobes of the maxilla; and setae on the inner margin of mesial and lateral lobes of pleopods 1-3. The length-to-width ratio was calculated to measure the elongation of the seventh pereopod propodus.

\section{Results}

\section{Population differentiation and isolation}

Unambiguously aligned $485 \mathrm{bp}$ sequences from 323 individuals revealed 15 different $16 \mathrm{~S}$ haplotypes defined by 57 variable sites. Haplotype and nucleotide diversity were very low, except in populations from Tama River, Katsuura River, Shimanto River, Okukubi River, and Urauchi River, which showed slightly higher haplotype diversities. Among the 15 haplotypes, only 3 haplotypes $(\mathrm{H} 1, \mathrm{H} 2$, and $\mathrm{H} 8)$ were shared among the localities. One is the most common haplotype (H2) shared by 241 individuals collected from all sampled localities from mainland Japan and was dominant at all sampled localities except Katsuura River. The other two haplotypes were shared by two 


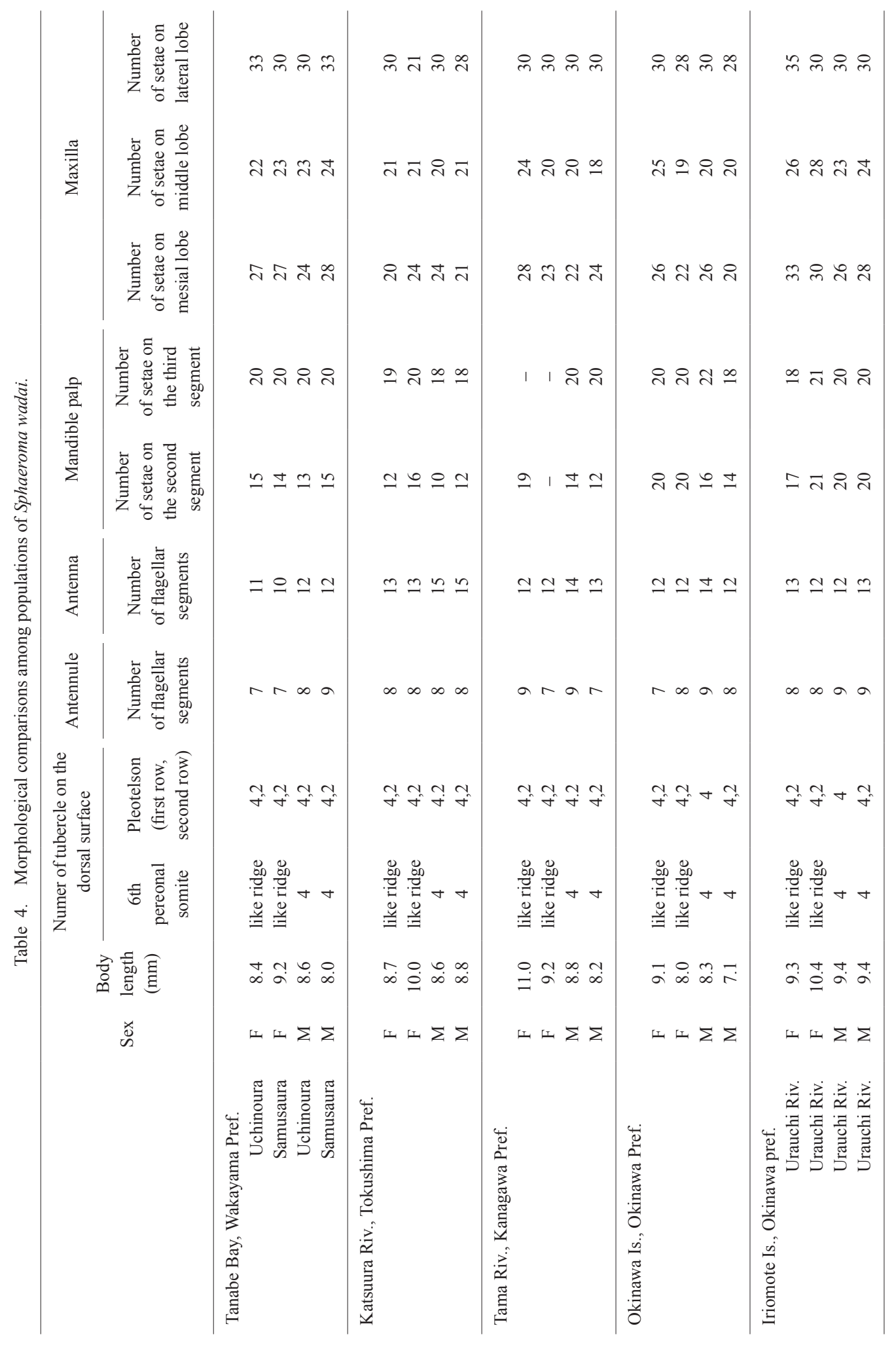




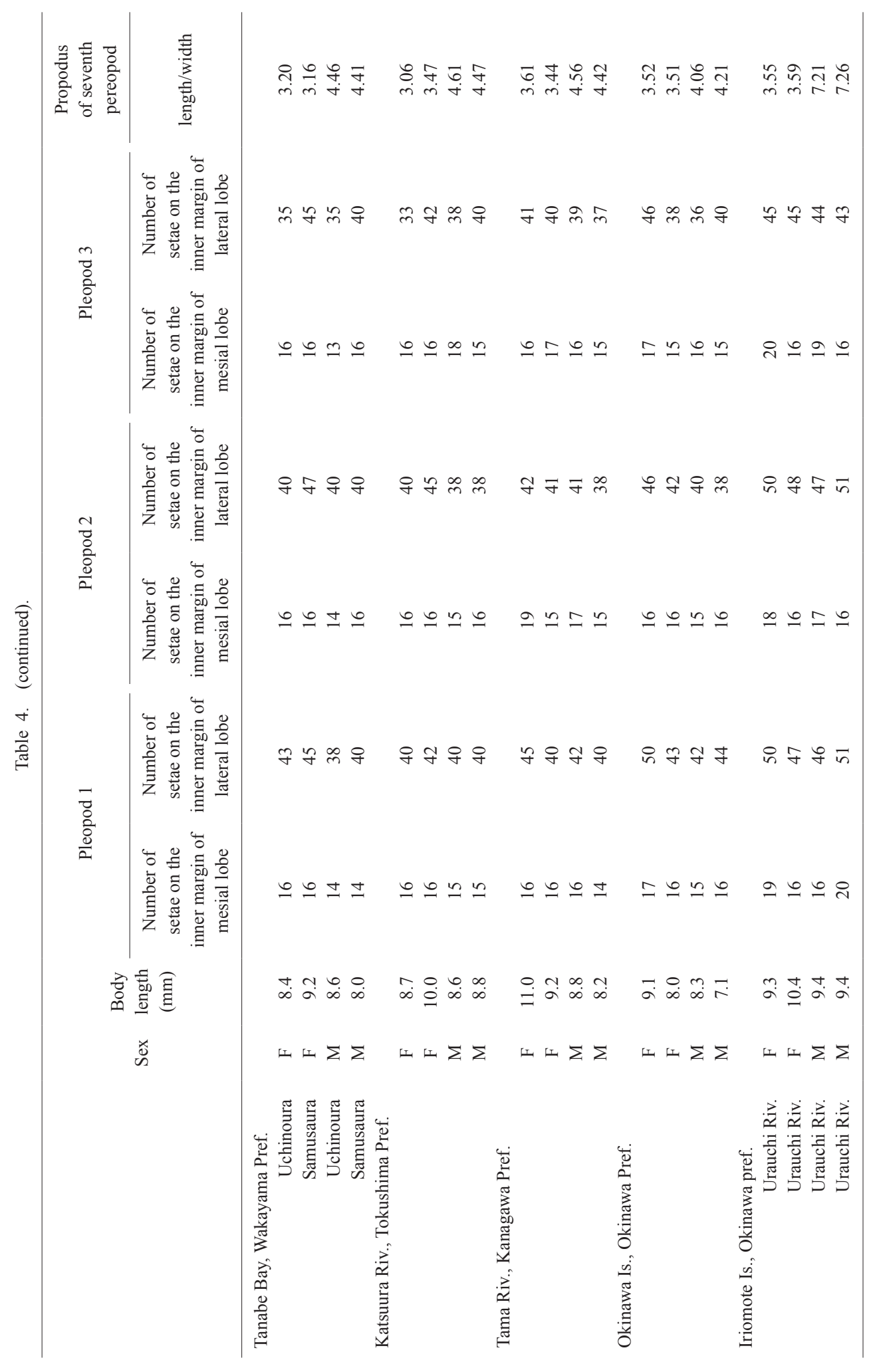


Table 5. Haplotype distribution and estimates of genetic diverstiy of Sphaeroma wadai from 13 sampling localities.

\begin{tabular}{|c|c|c|c|c|c|c|c|c|c|c|c|c|c|c|c|c|c|c|}
\hline \multirow{2}{*}{ No. } & \multirow{2}{*}{ Locality } & \multicolumn{14}{|c|}{ Haplotype } & \multirow{2}{*}{$n$} & \multirow{2}{*}{$\begin{array}{l}\text { Haplotype } \\
\text { diversity }\end{array}$} & \multirow{2}{*}{$\begin{array}{c}\text { Nucleotide } \\
\text { diversity }\end{array}$} \\
\hline & & H1 & $\mathrm{H} 2$ & $\mathrm{H} 3$ & $\mathrm{H} 4$ & H5 & H6 & $\mathrm{H} 7$ & $\mathrm{H} 8$ & H9 & H10 H11 & H12 & H13 & H14 & H15 & & & \\
\hline 1 & Isumi Riv., Chiba Pref. & & 29 & & & & & & & & & & & & & 29 & 0.000 & 0.0000 \\
\hline 2 & Tama Riv., Kanagawa Pref. & & 22 & & & & 1 & 7 & & & & & & & & 30 & 0.421 & 0.0010 \\
\hline 3 & Harai Riv., Mie Pref. & & 30 & & & & & & & & & & & & & 30 & 0.000 & 0.0000 \\
\hline 4 & Tanabe Bay, Wakayama Pref. & & 28 & & & & & & & & & & & & & 28 & 0.000 & 0.0000 \\
\hline 5 & Arida Riv., Wakayama Pref. & & 28 & & & & & & & & 1 & & & & & 29 & 0.069 & 0.0001 \\
\hline 6 & Katsuura Riv., Tokushima Pref. & 4 & 7 & 19 & & & & & & & & & & & & 30 & 0.545 & 0.0015 \\
\hline 7 & Kamo Riv., Ehime Pref. & & 15 & & & & & & & & & & & & & 15 & 0.000 & 0.0000 \\
\hline 8 & Shimanto Riv., Kochi Pref. & 1 & 25 & & 2 & 2 & & & & & & & & & & 30 & 0.306 & 0.0007 \\
\hline 9 & Kita Riv., Miyazaki Pref. & & 28 & & & & & & & 2 & & & & & & 30 & 0.129 & 0.0003 \\
\hline 10 & Manose Riv., Kagoshima Pref. & & 29 & & & & & & & & & & & & & 29 & 0.000 & 0.0000 \\
\hline 11 & Okukubi Riv., Okinawa Is., Okinawa Pref. & & & & & & & & & & & 1 & 2 & 1 & 26 & 30 & 0.251 & 0.0014 \\
\hline 12 & Urauchi Riv., Iriomote Is., Okinawa Pref. & & & & & & & & 5 & & 1 & & & & & 6 & 0.333 & 0.0007 \\
\hline 13 & Nakama Riv., Iriomote Is., Okinawa Pref. & & & & & & & & 7 & & & & & & & 7 & 0.000 & 0.0000 \\
\hline
\end{tabular}

Table 6. Pairwise $F_{\text {ST }}$ value between populations of 13 localities of Sphaeroma wadai.

\begin{tabular}{|c|c|c|c|c|c|c|c|c|c|c|c|c|c|}
\hline No. & Locality & 1 & 2 & 3 & 4 & 5 & 6 & 7 & 8 & 9 & 10 & 11 & 12 \\
\hline 1 & Isumi Riv., Chiba Pref. & & & & & & & & & & & & \\
\hline 2 & Tama Riv., Kanagawa Pref. & $0.158^{* *}$ & & & & & & & & & & & \\
\hline 3 & Harai Riv., Mie Pref. & 0.000 & $0.161^{* *}$ & & & & & & & & & & \\
\hline 4 & Tanabe Bay, Wakayama Pref. & 0.000 & $0.155^{* *}$ & 0.000 & & & & & & & & & \\
\hline 5 & Arida Riv., Wakayama Pref. & 0.000 & $0.142^{* *}$ & 0.001 & -0.001 & & & & & & & & \\
\hline 6 & Katsuura Riv., Tokushima Pref. & $0.526^{* *}$ & $0.427^{* *}$ & $0.531^{* *}$ & $0.521^{* *}$ & $0.504^{* *}$ & & & & & & & \\
\hline 7 & Kamo Riv., Ehime Pref. & 0.000 & 0.105 & 0.000 & 0.000 & -0.025 & $0.448^{* *}$ & & & & & & \\
\hline 8 & Shimanto Riv., Kochi Pref. & 0.026 & $0.113^{* *}$ & 0.028 & 0.024 & 0.022 & $0.436^{* *}-$ & -0.004 & & & & & \\
\hline 9 & Kita Riv., Miyazaki Pref. & 0.033 & $0.138^{* *}$ & 0.034 & 0.031 & 0.022 & $0.491^{* *}$ & 0.001 & 0.030 & & & & \\
\hline 10 & Manose Riv., Kagoshima Pref. & 0.000 & $0.158^{*}$ & 0.000 & 0.000 & 0.000 & $0.526^{* *}$ & 0.000 & 0.026 & 0.033 & & & \\
\hline 11 & Okukubi Riv., Okinawa Is., Okinawa Pref. & $0.939^{* *}$ & $0.900^{* *}$ & $0.940^{* *}$ & $0.938^{* *}$ & $0.934^{* *}$ & $0.892^{* *}$ & $0.921^{* *}$ & $0.914^{* *}$ & $0.930^{* *}$ & $0.939^{* *}$ & & \\
\hline 12 & Urauchi Riv., Iriomote Is., Okinawa Pref. & $0.999^{* *}$ & $0.990^{* *}$ & $0.999^{* *}$ & $0.999^{* *}$ & $0.998^{* *}$ & $0.986^{* *}$ & $0.998^{* *}$ & $0.993^{* *}$ & $0.997^{* *}$ & $0.999^{* *}$ & $0.986^{* *}$ & \\
\hline 13 & Nakama Riv., Iriomote Is., Okinawa Pref. & $1.000^{* *}$ & $0.991^{* *}$ & $1.000^{* *}$ & $1.000^{* *}$ & $0.999^{* *}$ & $0.988^{* *}$ & $1.000^{* *}$ & $0.994^{* *}$ & $0.998^{* *}$ & $1.000^{* *}$ & $0.988^{* *}$ & 0.028 \\
\hline
\end{tabular}

${ }^{*} P<0.05,{ }^{* *} P<0.01$

populations in Shikoku and Iriomote Island, respectively. A summary of the distribution of haplotypes according to locality is presented in Table 5. For samples from the Japanese mainland, the haplotype network showed a star-like shape, with rare haplotypes radiating from the central most common haplotype (H2) by one or two mutation steps (Fig. 1). The haplotypes identified from Iriomote Island (H8 and H11) were separated by many steps from those of all other sampled localities, and those identified from Okinawa Island were separated by several steps from those identified from the Japanese mainland.

Pairwise $F_{\mathrm{ST}}$ values for populations from Iriomote Island, Okinawa Island, and Katsuura
River and Tama River were significantly different from zero (except Tama River versus Kamo River), among which populations from Iriomote Island and Okinawa Island showed high $F_{\text {ST }}$ values (Table 6).

\section{Phylogenetic analysis}

The resulting tree showed $S$. wadai to be closely related to $S$. terebrans and its allied species (Fig. 2). Sphaeroma wadai from Iriomote Island clustered with Sphaeroma sp. from Seychelles, forming a sister taxon relationship with $S$. wadai from other sampled localities. Sphaeroma sieboldii was found to diverge early within the phylogeny, along with $S$. serratum, S. quadridentatum, S. quoianum, $S$. 


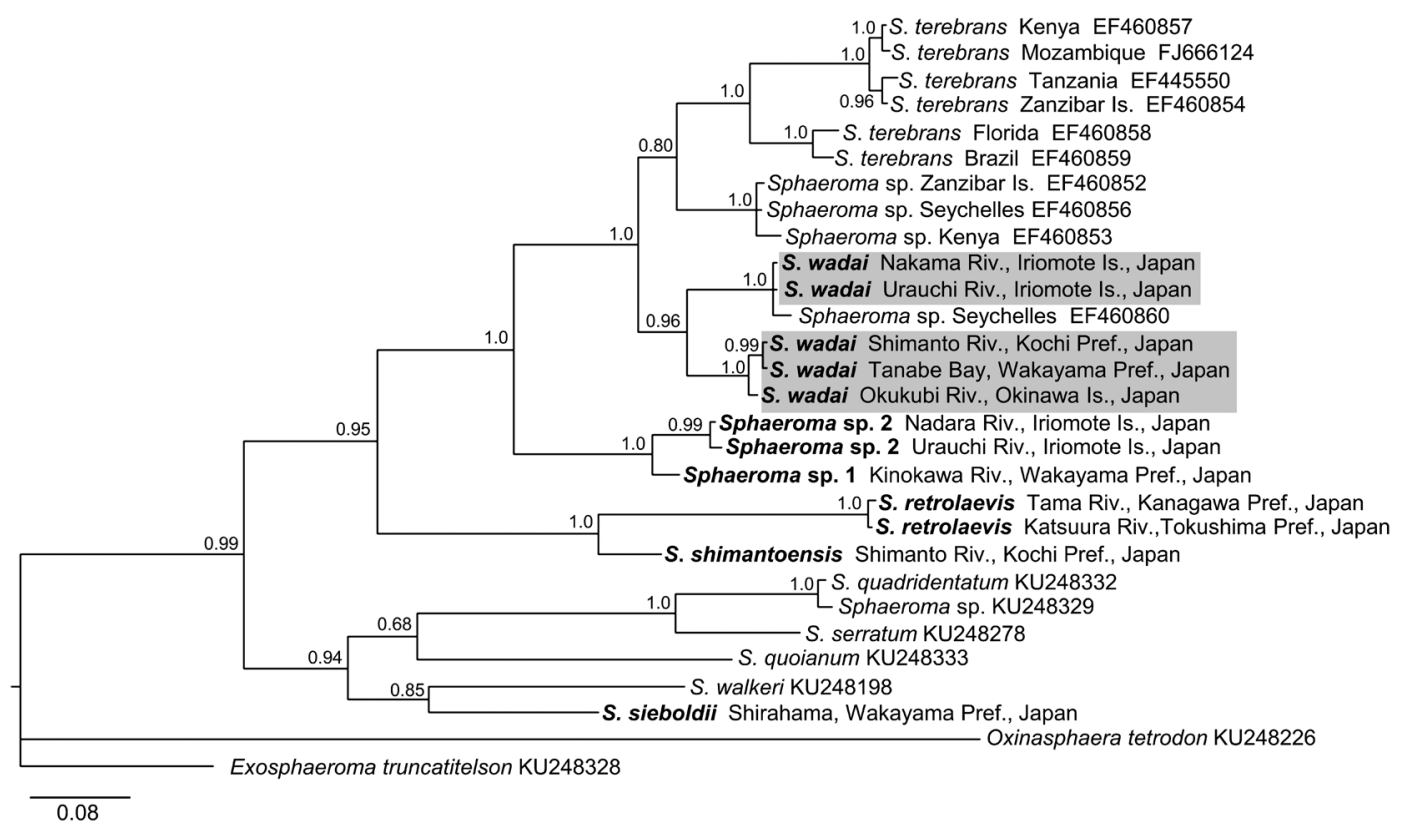

Fig. 2. Bayesian 50\% majority-rule consensus tree based on DNA sequences from the 16S rRNA gene (393 bp). Two sphaeromatid taxa, Oxinasphaera tetrodon and Exosphaeroma truncatitelson, were used as outgroups. Clade support expressed as posterior probabilities is shown around branches. New data for this study are bolded.

walkeri, and Sphaeroma sp. (KU248329). Sphaeroma shimantoesnsis and S. retrolaevis diverged subsequently, and Sphaeroma sp.1 and Sphaeroma sp. 2, diverged further late.

\section{Morphological variation}

Most of the characteristics examined did not show clear differences among the localities sampled (Table 4), but when comparing only male specimens there were some characteristics showing differences between the Iriomote Island and the other sampled localities. The number of setae on the inner margin of the lateral lobes of pleopods 1, 2, and 3 appeared slightly larger in males from Iriomote Island than those from other localities (pleopod 1: 46 and 51 in Iriomote, 38-44 in other localities; pleopod 2: 47 and 51 in Iriomote, 38-41 in other localities; pleopod 3: 43 and 44 in Iriomote, 35-40 in other localities). Also, the seventh pereopod propodus in male individuals from Iriomote Island was more elongated than that in individuals from the other sampled localities (length-to-width ratio: $4.06-4.61$ in Iriomote and 7.21-7.26 in the other localities; Fig. 3).

\section{Discussion}

Thus far, S. wadai has been reported from limited areas in Japan, such as Wakayama Prefecture (Nunomura, 1994, 2011; Murata and Wada, 2000), Kagoshima Prefecture (Nunomura, 2011), and Tokushima Prefecture (Nunomura, 2011, 2015; Wada, 2013). In the present study, we collected specimens from 10 localities along the Pacific coast of the Japanese mainland (from Chiba to Kagoshima Prefectures) and 3 from the Ryukyu Islands (Table 1, Fig. 1). The phylogenetic analysis revealed that the populations from Okinawa Island clustered in the same clade as populations from the Japanese mainland, but populations from Iriomote Island were closely related to the lineage that included Sphaeroma sp. from the Seychelles (Fig. 2). According to Baratti et al. (2011), 


\section{Dorsal view}
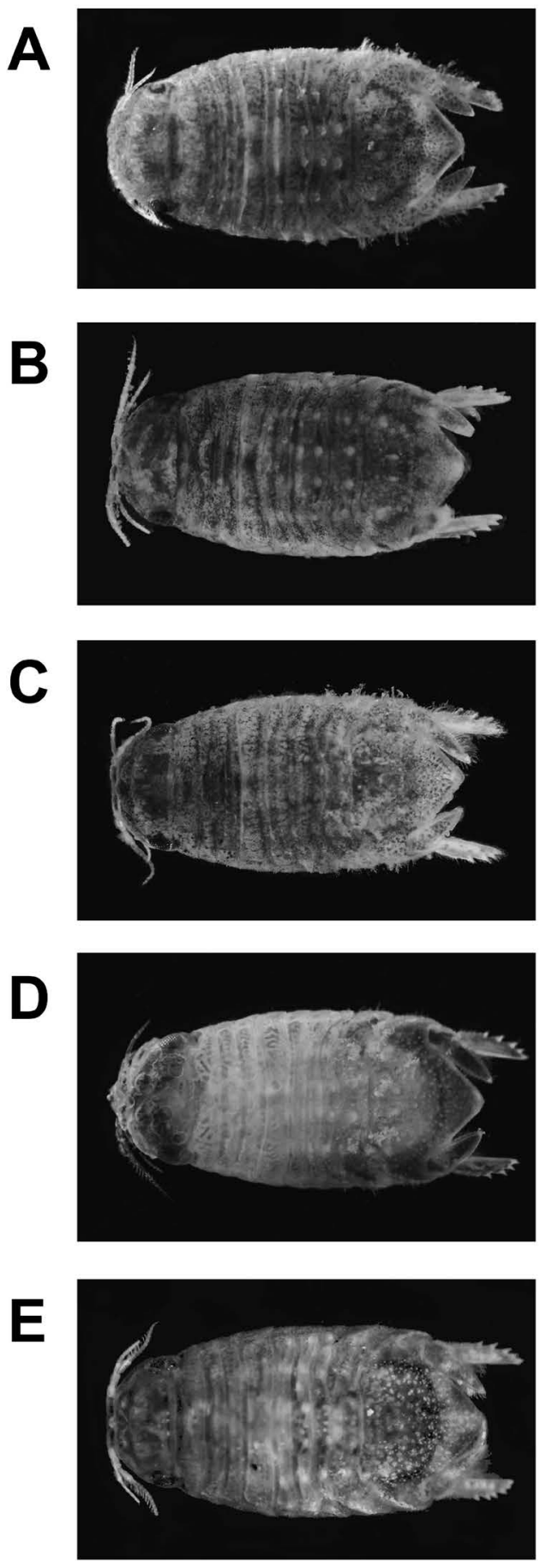

\section{Seventh pereopod}
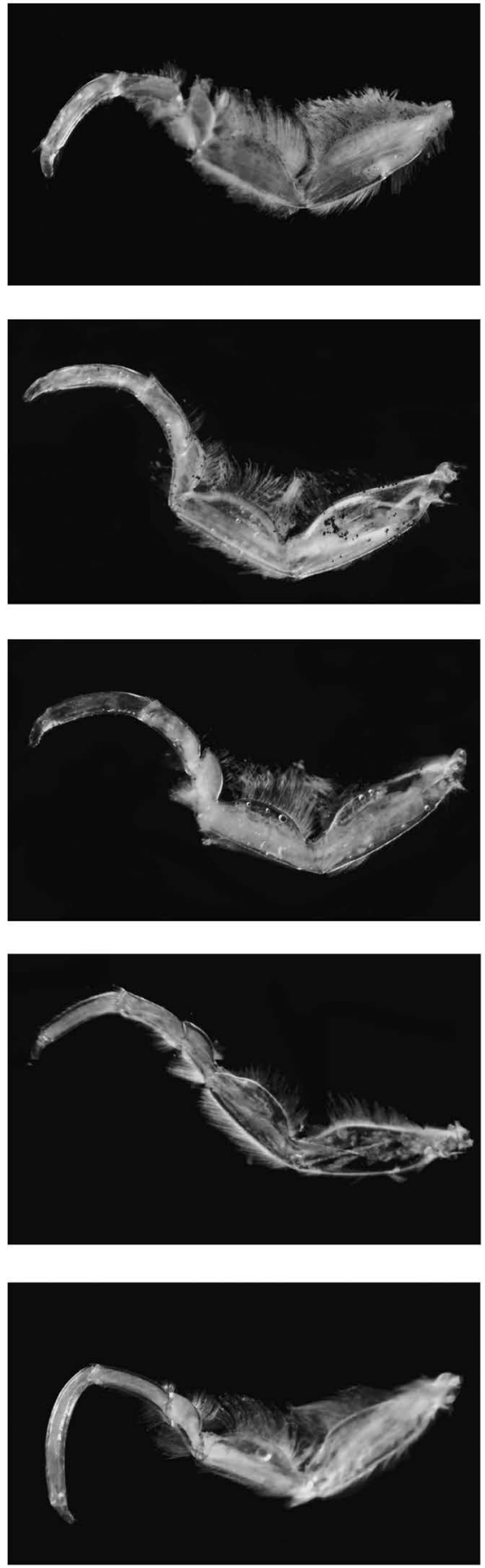

Fig. 3. Dorsal view and seventh pereopod of male Sphaeroma wadai from five populations that showed genetic differentiation. A, Samusaura, Tanabe Bay, Wakayama Pref., Male, 8.0 mm; B, Tama River, Kanagawa Pref., Male, 7.8 mm; C, Katsuura River, Tokushima Pref., Male, 8.0 mm; D, Okinawa Island, Okinawa Pref., Male, 8.3 mm; E, Iriomote Island, Okinawa Pref., Male, 9.4 mm. 
Sphaeroma sp. from the Seychelles (accession number: EF460860) formed a clade with specimens from Africa (Kenya, Zanzibar, and the Comoros Islands), which may represent a cryptic new species generated by past isolation of the $S$. terebrans population. The present phylogenetic tree suggests that Sphaeroma sp. from the Seychelles are more closely related to $S$. wadai than to $S$. terebrans and its allied species, particularly the population from Iriomote Island. The two lineages found in $S$. wadai were genetically highly diverged $(9.1 \%-10.3 \%$, uncorrected $p$-distance), probably representing a separate species, but they were not characterized by morphological variations in terms of diagnostic characters commonly used to discriminate Sphaeroma taxa. However, among male individuals, differences in some characters, such as propodus length of the seventh pereopod and the number of setae on the inner margin of lateral lobe of pleopods 1, 2, and 3 were observed.

The haplotype network and pairwise $F_{\mathrm{ST}}$ value showed that the population from Okinawa Island is genetically differentiated from the mainland populations. For samples from the Japanese mainland, the haplotype network showed a star-like shape (Fig. 1). The network structure and low genetic diversity of the mainland populations compared to that on Okinawa Island likely suggest a past bottleneck or founder event in the Japanese mainland population. Populations from Tama River (Kanagawa Prefecture) and Katsuura River (Tokushima Prefecture) shared the central most common haplotype $(\mathrm{H} 2)$, but the estimate of pairwise $F_{\mathrm{ST}}$ showed a significant difference compared with other populations, and these populations appeared to be genetically differentiated from the mainland populations.

The life form of $S$. wadai suggests limited gene flow in this species. Our result revealed that geographical differentiation is evident only among some studied localities. These results suggest that $S$. wadai is likely dispersed by rafting on floating substrates transported through the ocean currents, whereas genetic differentiation possibly occurs in places where physical barriers to dispersal sites are present. Our study investigated only one mitochondrial marker (16S rRNA), which is a slow-evolving genomic region and is frequently used to resolve phylogenetic relationships among species. Genetic differentiation among $S$. wadai populations from some localities in Japan was revealed in this study, which is likely to occur in more localities. Further studies using more highly variable markers for examining genetic variation across the entire distribution of $S$. wadai will allow us to obtain additional insight into their genetic and geographic population structure.

\section{Acknowledgments}

We thank Dr. Keiji Wada and Akihito Nomoto for providing specimens and K. Wada for his suggestions, corrections, and comments that have clearly improved the quality of the manuscript. We also thank Dr. Masashi Yoshimura and Ryunosuke Tobo for their assistance in field surveys and two anonymous reviewers who gave valuable comments on the manuscript. This study was supported by Grants-inAid of The Mikimoto Fund for Marine Ecology, Japan.

\section{$\square$ Literature Cited}

Baratti, M., Goti, E., \& Messana, G., 2005. High level of genetic differentiation in the marine isopod Sphaeroma terebrans (Crustacea Isopoda Sphaeromatidae) as inferred by mitochondrial DNA analysis. Journal of Experimental Marine Biology and Ecology, 315: 225-234.

Baratti, M., Filippelli, M., \& Messana, G., 2011. Complex genetic patterns in the mangrove wood-borer Sphaeroma terebrans Bate, 1866 (Isopoda, Crustacea, Sphaeromatidae) 
generated by shoreline topography and rafting dispersal. Journal of Experimental Marine Biology and Ecology, 398: 73-82.

Bandelt, H. J., Forster, P., \& Röhl, A., 1999. Median-joining networks for inferring intraspecific phylogenies. Molecular Biology and Evolution, 16: 37-48.

Borowsky, B., 1996. Laboratory observations on the life history of the isopod Sphaeroma quadridentatum Say, 1818. Crustaceana, 69: 94-100.

Boyko, C. B., Bruce, N. L., Hadfield, K. A., Merrin, K. L., Ota, Y., Poore, G. C. B., Taiti, S., Schotte, M., \& Wilson, G. D. F. (Eds.), 2008 onwards. Sphaeroma Latreille, 1802. In: World Marine, Freshwater and Terrestrial Isopod Crustaceans Database. Accessed through: World Register of Marine Species at http://www.marinespecies.org/aphia. php $\mathrm{p}=$ taxdetails\&id $=955716$ on 2018 08-28.

Excoffier, L, \& Lischer, H. E. L., 2010. Arlequin Suite ver 3.5 , a new series of programs to perform population genetics analyses under Linux and Windows. Molecular Ecology Resources, 10: 564-567.

Harrison, K., \& Holdich, D. M., 1984. Hemibranchiate sphaeromatids (Crustacea: Isopoda) from Queensland, Australia, with a worldwide review of the genera discussed. Zoological Journal of the Linnean Society, 81: 275-387.

Harvey, C. E., 1969. Breeding and distribution of Sphaeroma (Crustacea: Isopoda) in Britain. Journal of Animal Ecology, 38: 399-406.

Heath, D. J., \& Khazaeli, A. A., 1985. Population dynamics of the estuarine isopod Sphaeroma rugicauda. Estuarine Coastal and Shelf Science, 20: 105-116.

Jacobs, B. J. M., 1987. A taxonomic revision of the European, Mediterranean and NW African species generally placed in Sphaeroma Bosc, 1802 (Isopoda: Flabellifera: Sphaeromatidae). Zoologische Verhandelingen, 238: $1-71$.

Jensen, J. P., 1955. Biological observations on the isopod Sphaeroma hookeri Leach. Videnskabelige Meddelelser fra Dansk naturhistorisk Forening i Kjøbenhavn, 117: 305-339.

Kittlein, M. J., 1991. Population biology of Sphaeroma serratum Fabricius (Isopoda, Flabellifera) at the Port of Mar del Plata, Argentina. Journal of Natural History, 25: 1449-1459.

Kouwenberg, J., \& Pinkster, S., 1985. Population dynamics of three brackish water isopod species (Crustacea) in the lagoon system of Bages-Sigean (France). II. Life cycles, sexual activity and fecundity. Vie et Milieu, 35: 79-92.

Leigh, J. W., \& Bryant, D., 2015. PopART: Fullfeature software for haplotype network construction. Methods in Ecology and Evolution, 6: 1110-1116.

Messana, G., Bartolucci, V., Mwaluma, J., \& Osore, M., 1994. Preliminary observations on parental care in Sphaeroma terebrans Bate 1866 (Isopoda Sphaeromatidae), a mangrove wood borer from Kenya. Ethology Ecology \& Evolution, 6: 125-129.

Messana, G., 2004. How can I mate without an appendix masculina? The case of Sphaeroma terebrans Bate, 1866 (Isopoda, Sphaeromatidae). Crustaceana, 77: 499-505.

Murata, Y., \& Wada, K., 2000. Factors affecting distribution patterns of intertidal boring Sphaeromatid isopods (Crustacea). Japanese Journal of Benthology, 55: 25-33. [In Japanese]

Murata, Y., \& Wada, K., 2002. Population and reproductive biology of an intertidal sandstone-boring isopod, Sphaeroma wadai Nunomura, 1994. Journal of Natural History, 36: 25-35.

Nunomura, N., 1994. A new rock boring isopod crustacean belonging to the genus Sphaeroma collected from Tanabe Bay, Kii Peninsula, middle Japan. Bulletin of the Toyama Science Museum, 17: 1-5.

Nunomura, N., 2011. Crustaceans No. 2 (Isopod). Special Publication of the Toyama Science Museum No. 24, Toyama Science Museum. 
Nunomura, N., 2015. Isopod crustaceans (Arthropoda) from Shikoku, Western Japan. Kuroshio Biosphere, 11: 1-40, 10 pls. [In Japanese]

Ounifi-Ben Amor, K., Rifi, M., \& Ben Souissi, J., 2015. Description, reproductive biology and ecology of the Sphaeroma walkeri (Crustacea: Isopoda) alien species from the Tunis Southern Lagoon (northern Tunisia, central Mediterranean). Annales, Series Historia Naturalis, 25: 35-44.

Palumbi, S. R., 1996. Nucleic acids II: the polymerase chain reaction. In: Hillis, D. M., Moritz, C., \& Mable, B. K., (eds.), Molecular Systematics, Sinauer \& Associates Inc., Sunderland, Massachusetts. pp. 205-247.

Rambaut, A., Suchard, M. A., Xie, D., \& Drummond, A. J., 2014. Tracer v1.6, Available from http://tree.bio.ed.ac.uk/software/tracer/.

Ronquist, F., \& Huelsenbeck, J. P., 2003. MrBayes 3: Bayesian phylogenetic inference under mixed models. Bioinformatics, 19: 1572-1574.

Tanabe, A. S., 2007. KAKUSAN: a computer program to automate the selection of a nucleotide substitution model and the configuration of a mixed model on multilocus data. Molecular Ecology Notes, 7: 962-964.

Thiel, M., 1999. Reproductive biology of a wood-boring isopod, Sphaeroma terebrans, with extended parental care. Marine Biology, 135: 321-333.

Thompson, J. D., Higgins, D. G., \& Gibson, T. J., 1994. CLUSTAL W: improving the sensitiv- ity of progressive multiple sequence alignment through sequence weighting, positionsspecific gap penalties and weight matrix choice. Nucleic Acids Research, 22: 46734680.

Wada, T., 2013. The macrobenthic fauna in Yoshino River tidal flat, with discussion on conservation of estuary biodiversity (survey in 2011-2012). Bulletin of the Tokushima Prefectural Museum, 23: 87-111. [In Japanese]

Wetzer, R., Bruce, N. L., \& Pérez-Losada, M., 2018. Relationships of the Sphaeromatidae genera (Peracarida: Isopoda) inferred from 18S rDNA and 16S rDNA genes. Arthropod Systematics and Phylogeny, 76: 1-30.

\section{Addresses}

(JK): KYOUSEI Science Center for Life and Nature, Nara Women's University, Kitauoya Higashimachi, Nara 630-8506, Japan; (RY): Tateyama Marine Laboratory, Marine and Coastal Research Center, Ochanomizu University, Kouyatsu, Tateyama, Chiba 2940301 Japan; (NN): Noto Marine Laboratory, Institute of Nature and Environmental Technology, Kanazawa University, Ogi, Notocho, Ishikawa 927-0553, Japan

\section{E-mail address}

(JK): jun.yoshimura631@gmail.com 